\title{
John Calvin and postmodern spirituality
}

\author{
P.H. Fick \\ School of Ecclesiastical Studies \\ Potchefstroom Campus \\ North-West University \\ POTCHEFSTROOM \\ E-mail: rikus.fick@nwu.ac.za
}

\begin{abstract}
John Calvin and postmodern spirituality

Postmodernists reject universal truth claims and brand them as violent impositions on a person by powerful institutions. Postmodernist spirituality seeks for a more subjective, lifeexperience based attitude towards values and truths of the Bible and relationship in community. Careful consideration should be given to the issues of community, knowledge/truth, faith, and faith experience. This article will show that, in his "Institutes", Calvin gives ample attention to faith, the liberating truth about God as revealed in Jesus Christ, and to the Christian's intimate relationship with Him. Being in Christ, communion with Christ or the "unio mystica cum Christo" through faith as a central theme in Calvin's theology, needs to be rediscovered and re-applied to reformed spirituality as apologetic means in a postmodern world. This treasure should satisfy the kind of spirituality postmodernists yearn for.
\end{abstract}

\section{Opsomming}

\section{Johannes Calvyn en postmoderne spiritualiteit}

Postmoderniste verwerp enige aanspraak op universele waarheid en tipeer dit as gewelddadige dwang deur magtige instellings op 'n individu. Postmoderne spiritualiteit neig tot 'n meer subjektiewe, ervaringsgebaseerde houding teenoor die waardes en waarhede van die Bybel en 'n klem op verhoudings in 'n bepaalde gemeenskapsmilieu. Gemeenskap, kennis/waarheid, geloof en geloofservaring is kwessies wat in 'n postmoderne milieu fyn definiëring verg. Hierdie artikel toon aan dat Calvyn in sy "Institusie" ruim aandag gee aan geloof, die bevrydende waarheid oor God soos geopenbaar in Jesus Christus en aan die Christen se intieme verhouding met Hom. Hierdie gemeen- 
skap met Hom, of die "unio mystica cum Christo" deur die geloof, as 'n sentrale tema in Calvyn se teologie, is een van die skatte van die gereformeerde tradisie wat herontdek en weer op gereformeerde spiritualiteit toegepas moet word as 'n apologetiese middel in 'n postmoderne wêreld. Daar word aangetoon dat hierdie skat bevredigend behoort te wees vir daardie soort spiritualiteit waarna die postmoderne mens smag.

\section{Introduction: postmodernism, religion and truth}

Generally speaking, postmodernism is to be regarded as a rejection of many of the cultural certainties, principles and assumptions on which life in the West has been structured over the past couple of centuries. These assumptions, which constitute the centre of what is called modernism, include a belief in the inevitability of progress in all areas of human endeavour and the power of reason. Postmodernists are ever critical of universalising theories or metanaratives, as they are called by the postmodernist critic Jean-Francois Lyotard. To move from the modern to the postmodern is to embrace scepticism about what the Western culture stands and strives for.

Many mainline protestant denominations find themselves today in a postmodern world that lacks the coherence, certainty, and identity of its, not too distant, modernist past (Dekker, 2001:150). The postmodern temptation is also to turn away from (institutional) religion to spirituality and to entice people to create a self-styled spirituality. Increasingly, Westerners are looking eastward in search of a satisfying spirituality. Many of them, more at home in the Christian tradition, are turning to Eastern orthodoxy. Others are looking farther afield to the religions of the East. Postmodern spirituality can therefore take different shapes: from mystical experiences to committed and patently obvious actions (Tieleman, 1995:112, 113).

A reason for this burgeoning interest in spirituality is the fact that many values and accepted beliefs of orthodox religious thought are being seriously questioned. There is also a desire for deeper spiritual meaning, together with the belief that churches are too involved with internal organisational issues and not sufficiently concerned with spiritual matters. This leads to an increase of evangelistic crusades and an appeal to more emotional forms of Christianity (Kourie, 2006:28).

Individual identity has become a focus point. The self is the source of truth and reality and the individual is seen as creating his/her own meaning to a certain extent, rather than receiving it from outward 
(Mannion, 2007:4). To offset this tendency a Christian apologetic should emphasise spirituality as set within a framework of objective truth (Groothuis, 2000:164-165).

This, obviously, is not an easy task. Postmodernists reject universal truth claims and brand them as violent impositions on a person by powerful institutions; universal truth claims are, according to them, simply masks for ideology and the will to power (Vanhoozer, 2003: 11). The objectivity of human reason is called into question. There is an inbuilt precommitment to relativism or pluralism within postmodernism in relation to questions of truth (McGrath, 2001:113). Knowledge does not accumulate in any absolute sense, but rather grows and changes, eroding ignorance, as different value perspectives are illuminated and synthesised over time (Hodge \& Derezotes, 2008: 107-108). The postmodern society suffers from, as Groothuis (2000:21) calls it, "truth decay". The philosophy behind this, according to Thacker (2007:3), comes close to an epistemic nihilism.

The postmodern displacement of belief undermines religion understood in an epistemological sense; that is, religion as a body of commonly held beliefs which binds believers together, and insofar as these beliefs can be rationally justified as true, they establish a foundation for knowledge. Knowledge as justified true belief is, more or less, the epistemological focus of modern Western philosophy. Postmodernism tends to shift the focus of religion away from the epistemology of belief (Anderson, 2006:45).

The postmodern way to a new spirituality is more pleased with emphasis on a communicative and dialogical attitude which is prone to space and only then on the content of the doctrine (the purity and the borders thereof) (Tieleman, 1995:92).

As a result of the process of subjectivation in our postmodern society, the human experience has become more and more important in people's lives and their way of thinking. Postmodern spirituality seeks for religious integration. The rediscovery of the inner being poses a receptiveness for personal experience which is more than mere emotions. This further results in a more subjective, life-experience based attitude towards values and truths of the Bible. The well-known problem of revelation versus experience becomes important (Dekker, 2001:151). In a postmodern context, mind and feeling lose contact with each other, because the human reason (in modernity the instrument to get acquainted with reality) has introduced a split between mind and feeling (cf. Glas, 2000:19, 20). 
In terms of spirituality, a major theme, namely the quest for the mystical approach, seems especially prominent in the postmodern framework (Sheldrake, 2007:172-174). This new theological agenda often implies a move away from Christology and is reinforced by the problem of religious pluralism. If interest in religion is growing, the place of Jesus Christ has become an open question for many. Consequently, the significance of Jesus Christ is in danger of being reduced to a moral or spiritual example (Burger, 2008:2, 3).

I agree with Smith (2006:27) that much in the works of postmodernist theorists like Derrida, Lyotard and Foucault merits criticism, especially from a Christian perspective. There are, however, continuities between postmodernism and orthodox Christian faith, i.e. Christian faith as rooted in the Scriptures and attested in the historic creeds and confessions amplified by later reformed thought. These continuities are also found in Calvin's Institutes. I will focus on two such continuities. Calvin gives ample attention to the liberating truth and knowledge about God through Jesus Christ and secondly to the Christian's intimate relationship with Him through faith, or the unio mystica cum Christo. These are central themes in Calvin's theology and two of the treasures of the reformed tradition that need to be rediscovered and re-applied to reformed spirituality as evangelising and apologetical means in a postmodern world. I will also show that this treasure should satisfy the kind of spirituality postmodernist Christians yearn for in the light of their particular stance on truth/ knowledge and experience.

\section{Calvin on piety, truth and knowledge of God}

The fact that Calvin was a far more systematic writer than Martin Luther, doesn't help understanding his whole personality:

Whereas Luther's persona looms large on every page of his work, Calvin is inclined to be so 'private' that it is difficult to discern the person behind the pen and to discover the emotional heartbeat behind his intellectual drive to grasp the mysteries of God and the world. (Oberman, 1994:114.)

Calvin makes it from the outset of his Institutes (1.2.1) clear that "we cannot with propriety say there is any knowledge of God where there is no religion or piety". To the modern mind the word piety has lost its historic implications and status. It has become suspect, as bearing suggestions of ineffectual religious sentimentality or pretense. For Calvin and his contemporaries, pietas was an honest word, free from any unsavory connotation. It was a praiseworthy 
dutifulness or faithful devotion to one's family, country, or God. Calvin insistently affirms that piety and a sound knowledge of God are inseparable. At the first mention of this principle he briefly describes piety as "that reverence joined with love of God which the knowledge of his benefits induces". Pietas designates the right attitude of man towards God. This attitude includes true knowledge, heartfelt worship, saving faith, filial fear, prayerful submission, and reverential love. This word occurs with great frequency in Calvin's writings, and in the Institutes it keeps recurring like the ringing of a bell to call us back from the allurements of a secular intellectualism. For Calvin religion and piety are one and the same thing (Battles, 1969:38). "The whole life of Christians ought to be a sort of practice of godliness, for we have been called to sanctification." (Inst. 3.19.2.) As a matter of fact, the subtitle of the first edition of the Institutes states: "Embracing almost the whole sum of piety and whatever is necessary to know of the doctrine of salvation: a work most worthy to be read by all persons zealous for piety".

It is, of course, a temptation to equate Calvin's pietas with modern spirituality, especially because, traditionally, the terms spirituality and religion have been used interchangeably. More recently, however, scholars have begun to conceptualise them as distinct, yet overlapping constructs. Spirituality in general refers to the values to which we subscribe which give meaning and orientation to our lives. Whereas religion has connotations of institution, ritual, articulation of doctrine, et cetera, spirituality refers to something which is deeply personal, inward, experiential and authentic. It is possible to be religious without being spiritual, and to be spiritual without being religious. However, this is not to posit an irrevocable gulf between spirituality and religion. On the contrary, in many instances the former gives life to the latter (Kourie, 2006:26; cf. also Hodge \& Derezotes, 2008:108-109).

In any case, for Calvin piety and knowledge of God are inseparable: "No religion is genuine unless it be joined with truth." (Inst. 1.4.3.) Any other kind of knowledge of God is "cold and frivolous speculation", but "he who knows Him ... confides in Him as his guardian and protector, and unreservedly commits himself to his care" (Inst. 1.2.2). Calvin's own experience of conversion, together with his study of the sacred writings, gave him a vivid sense of the immediacy of God's dealing with men (Calvin, 1957:xviii).

One should not separate truth from saving faith, that is faith in Jesus Christ. As proof for this truth he quotes John 1:17: "the law was given through Moses; grace and truth came through Jesus Christ" 
(Inst. 2.7.16) and adds: "for thus we confess Him to be eternal and immutable truth" (Inst. 2.8.23). To grasp this truth, the work of the Holy Spirit is indispensable. In the Institutes 3.1.4 Calvin refers to 2 Thessalonians 2:13: the Thessalonians have been chosen by God "in sanctification of the Spirit and belief in the truth". He explains it as follows:

... he [the apostle] is briefly warning us that faith itself has no other source than the Spirit ... Christ promised to his disciples 'the Spirit of truth that the world cannot receive' that they might be capable of receiving heavenly wisdom.

Christ is the source of truth and wisdom, and the Christian grasp that truth through faith, and faith is a gift from the Holy Spirit. Calvin explains as follows: "Now, therefore, we hold faith to be a knowledge of God's will toward us, perceived from his Word. But the foundation of this is a preconceived conviction of God's truth." (Inst. 3.2.6.)

Now we shall possess a right definition of faith if we call it a firm and certain knowledge of God's benevolence toward us, founded upon the truth of the freely given promise in Christ, both revealed to our minds and sealed upon our hearts through the Holy Spirit. (Inst. 3.2.7.)

To know God is for Calvin of the utmost importance: "if all men are born and live to the end that they may know God, it is clear that all those who do not direct every thought and action in their lives to this goal degenerate from the law of their creation" (Inst. 1.3.3), "since the perfection of blessedness consists in the knowledge of God" (Inst. 1.5.1). We obtain salvation when we know that God is our merciful Father, because of the reconciliation effected through Christ (Inst. 3.2.7).

Although defining faith as knowledge, Calvin qualifies the working of faith as follows:

But there is ... a feeling of full assurance that in the Scriptures is always attributed to faith. It is this which puts beyond doubt God's goodness clearly manifested for us. But that cannot happen without our truly feeling its sweetness and experiencing it in ourselves. (Inst. 3.2.15.)

And here again we ought to observe that we are called to a knowledge of God: not that knowledge which, content with empty speculation, merely fits in the brain, but that which will be sound and fruitful if we duly perceive it, and if it takes root in the heart. For the Lord manifests himself by his powers, the force of 
which we feel within ourselves and the benefits of which we enjoy. (Inst. 1.5.9.)

When we call faith 'knowledge' we do not mean comprehension of the sort that is commonly concerned with those things which fall under human sense perception. For faith is so far above sense that man's mind has to go beyond and rise above itself in order to attain it. Even where the mind has attained, it does not comprehend what it feels. But while it is persuaded of what it does not grasp, by the very certainty of its persuasion it understands more than if it perceived anything human by its own capacity. Paul, therefore, beautifully describes it as the power 'to comprehend ... what is the breadth and length and depth and height, and to know the love of Christ, which surpasses knowledge'. (Inst. 3.2.14.)

Calvin's piety is fundamentally biblical, with an emphasis on the heart more than the mind, more in assurance than in comprehension (Beeke, 2004:125). Concerning faith his emphasis is not on objective knowledge of the articles of belief, but rather on a subjective act. Faith involves both intellect and will and thus both an apprehension of God's Word and a willing embracing of it. As Pitkin (2009:293) rightly states: "That the fiducial character of faith has not been done away with through the adoption of the terminology of knowledge is more than evident". This is in agreement with Dowey's (1965:3) observation: "The word knowledge ... is not purely noetic in Calvin's theology, and therefore its ubiquity is not ipso facto evidence of an intellectual faith".

In the postmodern world discussion of assurance and faith is usually conducted along the lines of a dichotomy of mind and feeling. For John Calvin, however, religion is not a matter of detached opinion or of acquiescence in traditional authority, but of the existential appropriation of divine truth. This "divine truth" is none other than knowledge of God, and to know Him, is to find Him (Inst. 1.1.1).

This must be understood against the background of his anthropology. Calvin divides the soul into two parts: mind and heart, i.e. intellect and will. The role of the intellect is to distinguish between good and evil; that of the will to choose the former and reject the latter (cf. Lane, 2009:276). In contemporary reformed dogmatics the heart is regarded as the centre of man's inner life. It refers to man's "I" with it's faculties of thinking, feeling and willing (Van Genderen \& Velema, 1992:325). From this angle it can be said, without contradicting Calvin, that faith has to do with al three these faculties. You believe from your heart or not at all. It is also a question of trust, 
love and inspiration - the marks of a true personal relationship. Knowledge is not unimportant, because there can be no faith without content. However, knowledge of God is not knowledge for the sake of knowledge, but knowledge which affects man profoundly. Knowledge is not a mere case of taking cognisance, but of existential involvement in the knowledge of God (cf. Brand, 2007:394). In a postmodern world this view of faith should be used as an apologetical tool in preaching and evangelisation.

\section{Calvin on the mystical union with Christ}

Calvin's emphasis upon union with Christ can be called the hallmark of both reformed doctrine and reformed spirituality (Canlis, 2004: 172). For him it is an essential part of Christian existence and of the believer's piety. As fundamental rule he states:

And in the first place we must know that as long as Christ remains outside of us, and we are separated from Him, all that He has suffered and done for the salvation of mankind remains useless and of no value for us. Therefore, to share with us what He has received from the Father, He had to become ours and to dwell within us. (Inst. 3.1.1.)

Also

... as if we ought to think of Christ, standing afar off and not rather dwelling in us! For we await salvation from Him not because He appears to us afar off, but because He makes us, ingrafted into his body, participants not only in all his benefits but also in Himself. (Inst. 3.2.24.)

In defining the means by which we are saved, Calvin, in his Institutes, also frequently uses the phrase "in Christ" rather than "by Christ" (e.g. Inst. 3.2.24, 40; 3.5.4; 3.14.17). In his commentary on Romans 6:11 he says that it is actually better to do it in this way, for the former phrase has more expressiveness and force and denotes the union with Christ. In uniting us to Himself and making us his members, Christ dwells in us and He "not only brings Himself close to us by an undivided bond of fellowship, but by a wondrous communion He grows with us daily more and more into one body until He becomes altogether one with us" (Inst. 3.2.24).

Calvin regards the nature and reality of this "mystical union" of the believers with Christ as one of the great mysteries of the gospel. He actually uses seven times in his Institutes the word arcanus or incomprehensibilis to describe the union with Christ (Inst. 2.12.7; 
3.11.5; 4.17.1, 9, 31, 33; 4.19.35; cf. Tamburello, 1994:89, 144). He also uses several metaphors to describe it: we are engrafted into Him; to grow into one body with Him; to "put Him on"; it is a "sacred wedlock" whereby we become "flesh of his flesh and bone of his bone" (Inst. 3.1.1; 3.1.3).

Calvin rejects any notion of a union of essences or a union of equals. Although expressions used by mystics are not foreign to Calvin, the distinction between Christ and the believer doesn't fall away. His reference is not to ontological communion, but to redemption and its fruits. The characteristic feature to be found with the mystics, namely "eine Unmittelbarkeit zu Gott" is not to be found in his writings (Kolfhaus, 1939:27, 126). Calvin therefore describes Osiander's notion of the iustitia Dei inhabitans, a "gross mixture" (Inst. 3.11.10; 3.1.3) between Christ and the believer. Instead he describes the union with Christ as essentially a spiritual union effected by the power of the Holy Spirit who is also the "Spirit of Christ" (Canlis, 2004:172).

In contrast with the medieval mysticism, the Reformation saw the community with Christ as the departing point, not the end of spiritual life. The community with Christ is connected to the justification through faith (De Vries, 1999:21) in such a way that one can say that we are not one flesh with Christ because we are declared righteous, but rather that we are declared righteous because we are one flesh with Christ (Metzger, 2003:206). While Calvin accepted a forensic notion of justification, he could never conceive of a justification in Christ which was not also a sanctification in Christ as well. Instead of Osiander's justification by the divine essence within, Calvin insisted that we participate in Christ's own human righteousness through being united with Him (Canlis, 2004:174). It is for this very reason that Metzger speaks of Calvin's "doctrine of moderate mystical union". Calvin's affirmation of the necessity of Christian holiness is rooted in the implications of the Christ/Spirit relationship for a proper understanding of union with Christ. If Christ the Mediator, who was and is filled with the Spirit of holiness, is made ours, we too share in the same Spirit (Garcia, 2006:231). Thus, the distinction between the once-for-all "alien" righteousness of Christ freely imputed on a sinner (justification) and the progressive holiness imparted through the indwelling Spirit in the regenerated person (sanctification) is obtained without separation. In fact, justifycation and sanctification are simultaneous realities within unio mystica (Tan, 2003). Only on this basis can the believer find him- 
/herself on a firm foundation from where piety can unfold itself (Van 't Spijker, 1995:22).

According to Calvin, the sacraments of Baptism and the Lord's Supper were instituted by Christ in order to make the union with Him continually effective in the life of the church. The visible signs, the bread and the wine which we eat and drink, and which represent the body and blood of Christ, show us how real the fact is that "our souls are fed by Christ just as our corporeal life is sustained by bread and wine" (Inst. 4.17.1). As the Lord's Supper is a repeatedly given sign to us that we live by continually drawing life from our union with Christ, so Baptism is a visible sign that we have really been initiated into the mystery of this union with the body of Christ (Inst. 4.18.19). However, Calvin's communion with Christ was not shaped by his doctrine of the Lord's Supper; rather, his emphasis on spiritual communion with Christ helped shape his concept of the sacrament (Beeke, 2004:128).

In discussing the mystery of how we can be so united to Christ as to become "bone of his bone and flesh of his flesh", Calvin does not forget that in the ascension Jesus Christ has taken his human nature beyond this earth to heaven where it will remain until his second coming in glory. It is therefore the Holy Spirit alone who can join things in heaven and earth. He speaks of the Holy Spirit as the link which binds us to Christ and also as the channel by which everything which Christ has is derived to us (Inst. 3.1.1), without subordinating the Spirit to Christ (cf. Tan, 2003).

Calvin states that Christian life begins with faith as a gift of the Holy Spirit through which man are bound to Christ. Calvin speaks in most exalted language about what the possession of faith does for the believing man. By faith we "obtain possession of the heavenly kingdom" (Inst. 3.2.1). Faith actually unites us to Christ and inserts us in his body (Inst. 3.2.30). "Christ cannot be known without the sanctification of his Spirit: therefore faith cannot possibly be disjoined from pious affection" (Inst. 3.2.8). As it is the "principal work" of the Holy Spirit to create in the heart of man the faith which unites him to Christ (Inst. 3.1.4), therefore it is equally true that we are united to Christ by the Holy Spirit alone and by faith alone (Wallace, 1982:21).

Van Ruler (1971:44) rightly states that Calvin makes room in his theology for the experiential (bevindelike) by not only emphasising the Christological, but also the Pneumatological dimension. Separation between the work of Christ and the work of the Holy Spirit 
tends to a separation of heart and mind and gives cause for a longing to the experiential dimension wide apart from faith in Christ. Community with Jesus Christ is at once the centre and circumference of true human existence. Christian faith has no authentic reality and the church has no unique mission in this world if one has no part in the life of Christ (Smedes, 1977:8).

In the postmodern period, we are moving away from reason by the anonymous self and moving toward relationship in community. Descarte's phrase "I think, therefore I am" is not relevant anymore. The postmodern catch phrase is "I belong, therefore I am". We are moving away from reason by the autonomous self and moving towards relationship in community (Long, 1997:61). The mystical unity between Christ and people means a very personal and intimate conjunction of the two in ecclesiastical perspective. The reason why Calvin is frequently called an "ecclesiastical man" is not, in the first place, due to the high value he assigns to the more visible side of the church with its offices and discipline, but due to his emphasis on the high form of unity between God and man (De Kroon, 2001:150). In this regard Thacker (2007:127) makes an important point with regard to postmodernists who reject Christianity:

... loving others represents the contours of what it means to participate in Christ, and hence know God. Christianity is not a theoretical discourse, but rather a practical agapeistic activity which is characterized by self-sacrificial service for the other.

In a postmodern situation Christians should therefore demonstrate that the Christian faith is not an oppressive, violent narrative, but rather one that is characterised by love (Thacker, 2007:36). New life can be breathed into theological systems that have become too closed in themselves and are too obsessed with the drive to logical consistency and technical articulation. It is especially the case with narrowly conceived theological constructs, when for instance, emphasis is placed only on the distance and kingship of God, and not also on God's nearness and tenderness (cf. Kourie, 2006:28).

\section{Conclusion}

Calvin played a major part in the forming of reformed theology and its writings, especially in his Institutes which do not proclaim a distance between God and the world, including the believer. He emphasises the necessity of the knowledge of God for a joyous life which is not only a matter of reason. The kind of knowledge that he poses is not an enlightenment optimism about the role of a sup- 
posedly neutral reason in the recognition of truth (cf. Smith, 2006: 28). In this a clear continuity with the postmodernist view of truth is to be recognised.

Calvin also constantly reminds the believers that they are called to a life of piety in the face of God, a piety that flows from an intimate, mystical union with Christ. He meticulously and intricately describes the inner work of the Holy Spirit and the abundant life we partake in. Our union with Christ is not to instantiate an ideal, but rather to be in fellowship with a Person. Our knowledge of God is not a mere human possession or grasping of a divine donum. When we know God, it is because we enter into an intimate personal relationship (cf. Thacker, 2007:63). This is a more than adequate message for a spiritual hungry postmodern world.

The Reformation was indeed born from a profound spiritual experience. It was not in the first place a theological movement, but a new form of spirituality which looked upon itself as a purer form of life in the face of God (cf. Brand, 2007:397). Recent studies of Calvin have also stressed that Calvin saw himself as a spiritual writer and not primarily as a dogmatician. For Calvin, union with Christ is an immediate consequence of faith, and is therefore fundamental to the Christian experience.

Calvin's doctrine of "being in Christ" gives an answer to the postmodern emphasis on relationship, but also on experience. His "being in Christ" embraces Christology and Pneumatology and gives cause to a reformed spirituality which can be described as not only an inner salvation experience of the heart in an encounter with God, but also a total living climate in disposition and habit (cf. Graafland, 1990:98).

Tamburello $(1994: 103,104)$ believes it not too bold to speak of a positive relationship between Calvin and mysticism and to point to Calvin's mystical sensitivity as exemplifying his warmer side, provided that you get people to agree on what mysticism means. Perhaps Tamburello would have found it useful to have the semantic tool of German and Afrikaans which are able to make a distinction between "Mystik/mistiek" and "Mystizismus/mistisisme". There are, indeed, various reformed theologians who have asked attention for a healthy reformed mysticism (Mystik/mistiek) which arises from true faith, not from emotion, such as A. Kuyper (1908: Introduction), J.J. van der Schuit (cf. Van 't Spijker, 1995:49), L. Floor (1953:10), T.L. Haitjema (cf. Brienen, 1978:48). Perhaps they should be heard. 


\section{List of references}

ANDERSON, P.M. 2006. Postmodernism and religion. (In Sim, S., ed. The Routledge companion to postmodernism. London: Routledge. p. 45-70.)

BATTLES, F.L. 1969. The piety of John Calvin: an anthology illustrative of the reformer of Geneva. Pittsburgh: Theological Seminary.

BEEKE, J.R. 2004. Calvin on piety. (In McKim, D.K., ed. The Cambridge companion to John Calvin. Cambridge: Cambridge University Press.

BRAND, S.J.P. 2007. 'n Pneumatologiese benadering tot teologie. Verbum et ecclesia, 28(2):384-411.

BRIENEN, T. 1978. Bevinding: aard en funksie van de geloofsbeleving. Kampen: Kok.

BURGER, J.M. 2008. Being in Christ: a biblical and systematic investigation in a reformed perspective. Eugene: Wipf \& Stock.

CALVIN, J. 1957. On the Christian faith: selections from the Institutes, commentaries, and tracts. Ed. with an introd. by J.T. Mcneill. New York: Bobbs-Merrill.

CALVIN, J. 1960. Institutes. Trans. by F.L. Battles. Westminster: Westminster Press.

CANLIS, J. 2004. Calvin, Osiander and participation in God. International journal of theology, 6(2):169-184.

DE KROON, M. 2001. The honour of God and human salvation: a contribution to an understanding of Calvin's theology according to his Institutes. New York: Clark.

DE VRIES, P. 1999. "Die mij liefgehad": de betekenis van de gemeenschap met Christus in de theologie van John Owen (1616-1683). Heerenveen: Groen.

DEKKER, G. 2001. Is a reformed belief possible in a postmodern society? (In Hendriks, H.J., ed. Reformed encounters with modernity: perspectives from three continents. Stellenbosch: ISSRC. p. 150-157.)

DOWEY, A. 1965. The knowledge of God in Calvin's theology. New York: Columbia University Press.

FLOOR, L. 1953. Gereformeerde mystiek. Haarlem: Breemouer.

GARCIA, M.A. 2006. Imputation and Christology of union with Christ: Calvin, Osiander, and the contemporary quest for a reformed model. Westminster theological journal, 68:219-251.

GLAS, G. 2000. Geloofzekerheid: over psychologische en antropologische voorwaarden om te geloven. (In Van Bekkum, K. \& Rouw, R., eds. Gelooven in zekerheid? Geloofzekerheid in de postmoderne tijd. Barneveld: De Vuurbaak. p. 19-34.)

GRAAFLAND, C. 1990. Gereformeerden op zoek naar God: Godsverduistering in het licht van gereformeerde spiritualiteit. Kampen: De Groot Goudriaan.

GROOTHUIS, D. 2000. Truth decay: defending Christianity against the challenges of postmodernism. Leicester: InterVarsity.

HODGE, D.R. \& DEREZOTES, D.S. 2008. Postmodernism and spirituality: some pedagogical implications for teaching content on spirituality. Journal of social work education, 44(1):103-123.

INST.

see CALVIN, 1960

KOLFHAUS, W. 1939. Christusgemeinschaft bei Johannes Calvin. Ansbach: Brügel. 
KOURIE, C. 2006. The "turn" to spirituallity. Acta theologica supplementum, 8:19-38.

KUYPER, A. 1908. Nabij God te zijn: meditatiën. DI. 2. Kampen: Kok.

LANE, A.N.S. 2009. Anthropology. (In Selderhuis, H.J., ed. The Calvin handbook. Cambridge: Eerdmans. p. 275-288.)

LONG, J. 1997. Emerging hope: a strategy for reaching the postmodern generations. Downers Grove: InterVarsity.

MANNION, G. 2007. Ecclesiology and postmodernity: questions for the church in our time. Collegeville: Liturgical Press.

McGRATH, A.E. 2001. Christian theology: an introduction. Oxford: Blackwell.

METZGER, P.L. 2003. Mystical union with Christ: an alternative to blood transfusions and legal fictions. Westminster theological journal, 65(2):201213.

OBERMAN, H.O. 1994. Initia Calvini. (In Neuser, W.H., ed. Calvinus Sacrae Scripturae professor: Calvin as confessor of Holy Scripture. Grand Rapids: Eerdmans. p. 113-154.)

PITKIN, B. 2009. Faith and justification. (In Selderhuis, H.J., ed. The Calvin handbook. Cambridge: Eerdmans. p. 288-299.)

SHELDRAKE, P. 2007. A brief history of spirituality. Oxford: Blackwell.

SMEDES, L.B. 1977. De nieuwe werklijkheid: existentie en situasie van de mens in gemeenskap met Christus. Hilversum: Benedictus.

SMITH, J.K.A. 2006. Who's afraid of postmodernism? Taking Derrida, Lyotard, and Foucault to church. Grand Rapids: Baker Academic.

TAMBURELLO, D.E. 1994. Union with Christ: John Calvin and the mysticism of St. Bernard. Louisville: Westminster John Knox.

TAN, S-K. 2003. Calvin's doctrine of our union with Christ. Quodlibet journal, 5(2), Oct.

THACKER, J. 2007. Postmodernism and the ethics of theological knowledge. Hampshire: Ashgate.

TIELEMAN, D. 1995. Geloofscrisis als gezichtsbedrog: spiritualiteit en pastoraat in een postmoderne cultuur. Kampen: Kok.

VAN GENDEREN, J. \& VELEMA, W.H. 1992. Beknopte gereformeerde dogmatiek. Kampen: Kok.

VAN RULER, A.A. 1971. Theologisch werk. DI. 3. Nijkerk: Callenbach.

VAN WYK, J.H. 1984. Calvyn oor die Christelike lewe. Pretoria: NG Kerkboekhandel.

VAN 'T SPIJKER, W. 1995. Gemeenschap met Chrstus: centraal gegeven van de gereformeerde theologie. Kampen: Kok.

VANHOOZER, K.J. 2003. Theology and the condition of postmodernity: a report on knowledge (of God). (In Vanhoozer, K.J., ed. The Cambridge companion to postmodern theology. Cambridge: Cambridge University Press.

WALLACE, R.S. 1982. Calvin's doctrine of the Christian life. Tyler: Geneva Divinity School Press.

\section{Key concepts:}

Calvin, John

postmodernism

spirituality 
Kernbegrippe:

Calvyn, Johannes

postmodernisme

spiritualiteit 
